\title{
ASPECTS OF THE INTRODUCTION OF TRANSDISCIPLINARY TO THE TEACHING OF PHYSICS AND TECHNICS DISCIPLINES IN THE CONDITIONS OF DIGITAL AND STEM TRANSFORMATION OF EDUCATION
}

\author{
Kuzmenko O. S. \\ Doctor of Pedagogical Sciences, Associate Professor, \\ Professor at the Department of Physics and Mathematics \\ Flight Academy of the National Aviation University \\ Kropyvnytskyi, Ukraine, \\ Senior Researcher at the Department of Information and Didactic Modeling \\ "Junior Academy of Sciences of Ukraine" \\ Kyiv, Ukraine
}

STEM-education and the Concept of digital Agenda [7] provide for the integration of natural, technical, humanities and the expansion of innovation and educational space for students of higher education institutions (HEI).

The introduction of the STEM training system in physics and technics disciplines in Ukrainian free economic zones will contribute to 1) modernization of the system of psychological-pedagogical, methodological, practical training of future specialists in the technical field of training; 2) application of transdisciplinary, systemic, interdisciplinary, professionally-oriented approaches to the educational process in physics, which involves the development of personality, aimed at active and constructive participation in modern digital transformation processes of education in Ukraine; 3) establishing the production of domestic educational equipment and teaching aids in the context of STEM-education.

The definition of "transdisciplinarity» began to be considered in the 80's of the twentieth century. The scientist J. Piaget outlined transdisciplinarity through the interaction between research areas [1]. Erich Jancz defined transdisciplinarity as a new space without stable boundaries between disciplines, as a new branch of knowledge that must necessarily be super- or hyperdiscipline. Such transdisciplinarity should be «the coordinator of all disciplinary and interdisciplinary systems of learning and innovation based on a common axiomatic approach» [3].

Andre Likhnerovich perceived transdisciplinarity as «cross-cutting games» capable of describing «the homogeneity of theoretical activity in various fields of science and technology, regardless of the field where this 
activity is carried out». And, of course, this theoretical activity could be formulated only in mathematics language [1].

Transdisciplinary integration of information resources in his research was substantiated by scientist O. Stryzhak [4], developing a model of information environment taking into account the transdisciplinary approach through the manifestation of recursive and reflexive properties of sets of taxonomic and operational features of ontologies $[5 ; 6]$.

Consider the definition of transdisciplinary according to the research of scientist E. Judge [2], which we used in the process of teaching physics in HEI technics profile: 1) transdisciplinarity-0 (introduction of elements of metaphor); 2) transdisciplinarity-1 (interrelation of separate disciplines; formation of logical meta-frameworks); 3) transdisciplinarity-2 (internal connection with the personal experience of the researcher); 4) transdisciplinarity-3 (use of general metaphors that have fundamental cognitive value).

The desire of physics and technics disciplines to integrate into the process of finding solutions to complex multifactorial problems of nature and society within the picture of a single world has found its realization in one of the varieties of transdisciplinary approach - transdisciplinarity-4.

Consider, as an example of the use of the fundamental physics concept of symmetry, in the process of teaching students in the disciplines of physics, theoretical mechanics and resistance of materials in higher education institutions of the technical profile, taking into account the transdiplinary approach to learning.

Any action of general form can be represented as the sum of two actions, one of which is symmetric and the other is obliquely symmetric or inversely symmetric. For example, the concentrated force $\mathrm{P}_{1}$ (Fig. 1, $a$ ) is replaced by two symmetrical and two obliquely symmetrical concentrated forces $\mathrm{P}_{1} / 2$, evenly distributed load $q$ - two symmetrical (Fig. 1,b) and two obliquely symmetrical (Fig. 1, c) loads intensity $q / 2$. If the action is initially symmetric (force $\mathrm{P}_{2}$ ) or obliquely symmetric, then its decomposition is not carried out.

Symmetrical and obliquely symmetrical can be decomposed load, which is applied in symmetrical sections, but has different values. If we consider the two concentrated moments $\mathrm{M}_{1}$ and $\mathrm{M}_{2}$ (Fig. 2,a) are replaced by two pairs of concentrated moments. The moments of the first pair are equal to $\left(\mathrm{M}_{1}+\mathrm{M}_{2}\right) / 2$ (Fig. 2, $b$ ) and are directed symmetrically.

The magnitudes of the moments of the second pair, which are directed obliquely, are $\left(\mathrm{M}_{1}-\mathrm{M}_{2}\right) / 2$ (Fig. 2, c). In this case, initially, the obliquely symmetric force $P$ does not decompose.

To simplify the calculation by the method of forces of symmetric system, the main system must be symmetrical or conditionally symmetrical. It is also 
necessary that the conditions of symmetry and oblique symmetry correspond to the basic unknowns.
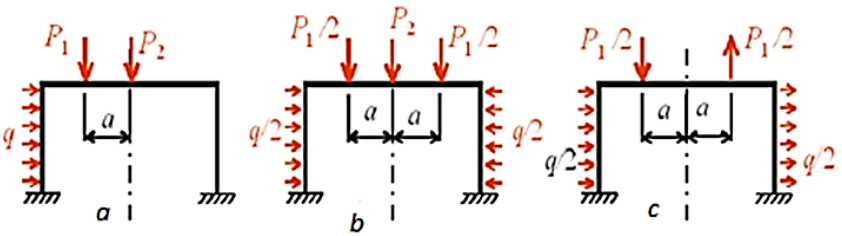

Fig. 1.
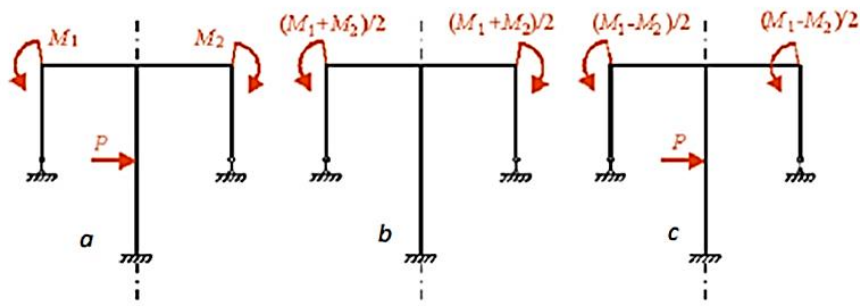

Fig. 2.

As a result of the research and the above, we state that the expediency of subordinating the content of educational material in physical and technical disciplines is based on fundamental concepts, one of which is symmetry. Familiarization and study by students of the concept of symmetry and its principles will contribute to the formation of modern scientific thinking, as well as provide systematization of knowledge in physics in solving problems in various sections of physics and the formation of the scientific worldview and STEM-skills of the XIX century.

\section{References:}

1. André Lichnerowicz. Mathématique et transdisciplinarité, in Léo Apostel et al, 1972.

2. Judge A. Conference Paper. 1st World Congress of Transdisciplinarity, Union of International Associations, 1994. Available: http://www.uia.org/uiadocs/aadocnd4.htm.

3. Erich Jantsch. Vers l'interdisciplinarité et la transdisciplinarité dans l'enseignement et l'innovation, in Léo Apostel et al, 1972.

4. Стрижак О. Є. Трансдисциплінарна інтеграція інформаційних ресурсів: дис. д-ра техн. наук. Київ, 2014. 470. 
5. Стрижак А. Е. Инвариантные задачи онтологических систем. Information technologies \& knowledge, 2014. № 8. C. 356-360.

6. Трансдисциплінарне представлення інформації за допомогою інтерактивних документів. О. П. Мінцер, В. В. Приходнюк, О. С. Стрижак, О. М. Шевцова. Медична інформатика та інженерія. 2018. Вип. 1 (41). С. 47-52.

7. Цифрова адженда України - 2020. Концептуальні засади (версія 1.0). Проєкт. (2016). URL: https://ucci.org.ua/uploads/files/ 58e78ee3c3922.pdf

\title{
DOI https://doi.org/10.30525/978-9934-26-043-8-11
}

\section{THERMAL VACUUM PROCESS FOR OBTAINING NANO-DISPERSED MATERIALS}

\author{
Kutovyi V. O. \\ Doctor of Technical Sciences, (Senior Researcher) Leading Researcher \\ National Scientific Center "Kharkiv Institute of Physics and Technology" \\ Malykhin D. G. \\ Candidate of Sciences in Physics and Mathematics, Senior Researcher \\ National Scientific Center "Kharkiv Institute of Physics and Technology" \\ Kharkiv, Ukraine
}

An actual problem of physics is development of scientific and technical principles of creating nanostructured materials for the needs of modern technology.

On the basis of the performed theoretical and experimental studies, an energy-efficient pulse-shock thermal vacuum method for continuous production of nanodispersed materials had been developed. The method is based on the principle of combining high-speed processes of both evacuation and thermal heating to a predetermined temperature, which last occurs during direct contact of the initial powder material with the inner surface of a hollow heater [1].

For the closest contact with the starting powder material, the heater is made in the form of a helical spiral. The physical principle of this technique is that the decrease in pressure inside the heating element, produced by a vacuum pump, creates a gradient that stimulates an intense turbulent flow of powder and effective contact of particles with the inner surface of the heater. 